\title{
Täiskasvanute õppimisest ja õpetamisest. Sissejuhatus raamatusse
}

\author{
Larissa Jõgi \\ Tallinna Ülikooli haridusteaduste instituut \\ Rain Mikser \\ Tallinna Ülikooli haridusteaduste instituut \\ Tartu Ülikooli haridusteaduste instituut
}

\begin{abstract}
Märja, T., Jõgi, L., Lõhmus, M. (2021). Andragoogika. Raamat täiskasvanute oppimisest ja ópetamisest. Tartu: Kirjastus ATLEX.
\end{abstract}

Väljaanne „Andragoogika. Raamat täiskasvanute õppimisest ja õpetamisest“ ilmus 2021. aasta alguses kirjastuses ATLEX. Autoriteks on andragoogika kui teadus- ja õppevaldkonna kogenud arendajad: Tallinna Ülikooli emeriitprofessor Talvi Märja, Tallinna Ülikooli dotsent Larissa Jõgi ning Tallinna Tehnikaülikooli lektor Merle Lõhmus. Raamat koosneb neljast osast. Esimene osa (autor Talvi Märja) keskendub täiskasvanuhariduse teooriate ja kontseptsioonide arenguloole ja tänapäevale. Teine osa (Larissa Jõgi) võtab kokku täiskasvanute õppimise ja õpetamise põhimõtted ning täiskasvanute koolitaja professionaalse arengu, rollide, identiteedi ja väärtuste alused. Kolmas osa (Merle Lõhmus) käsitleb õpikeskkonna olemust ja aluseid täiskasvanuõppes. Neljas osa (Talvi Märja) käsitleb õppivat ühiskonda ning óppimise vajalikkust täiskasvanueas.

Raamatu sihtrühmana märgivad autorid inimesi, kelle töö on seotud täiskasvanute õppimise, õpetamise ja koolitamisega ning täiskasvanuõppe arendamisega, samuti andragoogika eriala üliõpilasi.

Eri koolkondade, keeleruumide ja haridustraditsioonide paljususe tõttu on andragoogika eripära ning seos üldpedagoogikaga tänini vaidlusteemaks (huviline leiab lühiülevaate Larissa Jõe artiklist „Andragoogika“, mis ilmus 2013. aastal kogumikus „Haridusleksikon“). Nii võib teiste vanuserühmade õppimise ja õpetamisega seotud lugejal tekkida küsimus, kas ja mida on täiskasvanuõppes tõeliselt eripärast, võrreldes õppimisega teistes vanuseastmetes. Seetõttu eeldab raamatu eesmärgi ja uudsuse tutvustamine laiemale haridusüldsusele põgusat ülevaadet andragoogika arenguloost ning olulisimatest varasematest eestikeelsetest andragoogikaalastest väljaannetest.

Kuigi elukestvat õpet seostatakse sageli viimaste kümnendite, eelkõige 21. sajandi arengu ja vajadustega, on elukestva õppe idee, samuti andragoogika mõiste tegelikult sajanditevanused. Elukestva õppe põhimõttest 
lähtusid juba antiikfilosoofid, aga ka 17. sajandi tšehhi pedagoog Jan Amos Komenský. Andragoogika mõiste esmakasutus pärineb teadaolevalt 1833. aastast, olles seega vaid veidi hilisem Johann Friedrich Herbarti teosest „Üldine pedagoogika" (1806), mis pani aluse pedagoogikale kui iseseisvale teadusdistsipliinile. Viimase sajandi jooksul on nii Mandri-Euroopas kui ka inglise keeleruumis, eelkõige USA-s, ilmunud andragoogika süsteemseid käsitlusi autoritelt, kellest on kujunenud valdkonna klassikud. Neist kõige nimekam on ameeriklane Malcolm S. Knowles. Temalt pärineb ka andragoogika ja pedagoogika põhimõttelise eristamise idee ning andragoogilise mudeli kontseptsioon, mis andragoogika hilisemas arengus on osutunud vaieldavaks, samas edasiviivaks teoreetiliseks aluseks.

Eesti kontekstis tuleb mainida, et sel sügisel möödub 35 aastat andragoogika kui teadus- ja õppevaldkonna loomisest Tallinna Ülikoolis. Seega on raamat selle tähtpäeva väärikaks tähistuseks. Mõistagi on valdkonna püsimajäämise eeldanud piisavat rahvusvahelisel tasemel teadus- ja õppetööd. Samas on eestikeelsele lugejaskonnale oluline, kuhu paigutub värske raamat olemasoleva eestikeelse andragoogikaalase kirjanduse hulgas. Seni avaldatu ei ole olnud iseäranis arvukas, ent ei saa ka öelda, et tutvustatav raamat oleks ilmunud täiesti tühjale kohale. Varasematest väljaannetest tuleb märkida Aino Kureniidu raamatut „Täiskasvanupedagoogika“ (1986) ning siin tutvustatava raamatu autorite ühisväljaannet „Andragoogika: raamat õppimiseks ja õpetamiseks“ (2003). Lühiülevaade andragoogika mõistest ja arenguloost leidub Larissa Jõe mainitud artiklis „Andragoogika“ (2013). Filosoofilise ülevaate andragoogikast pakub Claudia Tinn oma magistritöös (2020). Terviklikku ja süsteemset käsitust andragoogika mõtteloost ja põhiteemadest ükski nimetatud teos aga ei anna. Ka tutvustatava raamatu autorite 2003. aastal ilmunud väljaanne oli ideelt ja käsitluselt pigem didaktiline kui mõttelooline ja kontseptuaalne. Selle lünga täitmisega eestikeelses erialases kirjanduses püüab uus raamat vähemasti algust teha.

Raamat on jätk samade autorite 2003. aastal ilmunud väljaandele. Eelnimetatud üsna nõudlik eesmärk eeldas autorite vahel tõsiseid kaalutlusi ja arutlusi nii uue raamatu teoreetilise suunitluse kui ka ülesehituse küsimustes. Eelnevat arvestades oli selge, et raamat peab sisaldama ülevaadet andragoogika mõiste ja kontseptsiooni arenguloost ja hetkeseisust, samuti ühiskondlike protsesside põhjalikku käsitlust, mis toetavad täiskasvanute õpet ja täiskasvanute õppimise väärtustamist. Eelkõige keskendub neile küsimustele Talvi Märja raamatu esimeses ja neljandas osas.

Edasi leppisid autorid kokku kolmes põhiseisukohas. Esiteks tugineb teos laiale arusaamale õppimisest: óppimine on pidev arengukeskne protsess, mis toimub indiviidi sotsialiseerimise ja sotsialiseerumise käigus ning hõlmab kõiki 
eluvaldkondi. See arusaam on täiskasvanuõppe tunnustatud teoreetiku Peter Jarvise sotsiaalse ópiteooria üks olulisimaid aluseid. Teise, eelnevast lähtuva põhiseisukoha järgi eeldab õppimine mitmekesiseid võimalusi ning avatud õpikeskkondi, mida kõigil täiskasvanutel on õigus kasutada, et võtta oma õppimise eest vastutus, õppimise üle autonoomselt otsustada ja seda mõtestada. Kolmas põhiseisukoht on avatud ja loominguline arusaam õpikeskkonnast: õpikeskkond on kõik, mis inimesi ümbritseb ja mõjutab ning mis omab nende jaoks tähendust. Õpikeskkonnad on seotud sotsiaalse, haridusliku ja kultuurilise kontekstiga. Nende loomisel ja märkamisel tuleb toetada täiskasvanu õpipotentsiaali ja autonoomia arengut.

Peatükid sisaldavad mõistete ja terminite seletusi, teooriate põhiseisukohti ning arutelu, soovituslikku kirjandust, näiteid uurimustes osalejatega tehtud intervjuudest ja autorite kommentaare.

Lugeja tõenäoliselt märkab, et kohati käsitatakse peatükkides korduvalt samu protsesse, nähtusi ja teooriaid. Korduvus ei ole siiski juhuslik. Need lähtuvad erinevatest kontekstidest ja vaatenurkadest. Sellist lähenemist peetakse suuresti õppeotstarbelise teksti ning eri autorite puhul tavapäraseks ja pigem soovitatavaks praktikaks.

Ilmselt nõustub iga õppimiskäsituste aluseid vähegi tundev lugeja, et ei óppimis- ega õpetamisoskus ole täielikult omandatav üksnes kirjandust lugedes. Parimgi raamat saab olla üksnes abiks inimese enese nähtu ja kogetu mõtestamisel. Teos võib seega olla toeks valikute tegemisel, kriitilisel eneseanalüüsil ja uute võimaluste avastamisel.

Ehkki autorid on pööranud suurt tähelepanu raamatu sisuloogika järjekindlusele, ei tähenda see, et raamatut peaks tingimata lugema järjest esimesest peatükist lõpuni. Lugeja on kutsutud teost uudistama iseseisvate osade kaupa või süvenema meelepärastesse teemadesse. Loodetavasti aitab selline lähenemine juurde tuua täiskasvanuõppe ja andragoogika uusi entusiaste. 